\title{
Otel İşletmelerinde Yönetici Yetkinliklerinin Analizi: İzmir Örneği
}

\author{
Analysis of Hotel Managers Competencies: The Case of İzmir
}

\author{
Nilgün AVCl* \\ *Yrd. Doç. Dr., Ege Üniversitesi, Çeşme Turizm ve Otelcilik Yüksekokulu, 35000, Dalyanköy, Çeșme, İzmir. \\ E-posta: nilgun.avci@ege.edu.tr
}

\section{MAKALE BILGILERI \\ Makale ișlem bilgileri:}

Gönderilme tarihi: 28 Şubat 2014

Birinci değerlendirme: 13 Nisan 2014

İkinci değerlendirme: 13 Mayıs 2014

Kabul: 20 Mayıs 2014

\section{Anahtar sözcükler:}

Yönetici yetkinlikleri, Otel yöneticileri, Şehir otelleri, Resort oteller.

\section{ARTICLE INFO}

Article history:

Submitted: 28 February 2014

Resubmitted: 13 April 2014

Resubmitted: 13 May 2014

Accepted: 20 May 2014

Key words:

Managers competencies, Hotel managers, City hotels, Resort hotels.

\begin{abstract}
ÖZ
Otel yöneticilerinin etkinliğinde, kritik bir öneme sahip olan yetkinliklerin belirlenmesinin, turizm sektörünün bașarısına katkı sağlayacağı düșünülmektedir. Yetkinlikler; bireylerin iș performansı için gerekli olan bilgi, beceri, yetenek, tutum ve özellikleri kapsamaktadır. Bu çalışmanın amacı; otel yöneticilerinin yetkinliklerini belirlemek ve yetkinliklerin şehir otelleri ile resort oteller açısından farklı olup olmadığını araştırmaktır. Araştırmada; verileri toplamada ve analizde, nicel yöntem kullanılmıștır. Sehir otellerinin ve resort otellerin birlikte analiz edilebileceği alan olarak İzmir belirlenmiş, İzmir merkez ilçe Konak'ta şehir otelleri ile Çeşme'de bulunan resort oteller çalışmaya dahil edilmiştir. Çalışma için veriler üç, dört ve beş yıldızı otellerden toplanmıştır. Toplanan verilerin analizinde SPSS 20 programı kullanıImıștır. Öncelikle güvenilirlik ve geçerlilik analizleri yapılmıș, hipotezler fark analizleriyle test edilmiștir. Analizlerden elde edilen bulgular, yönetici yetkinliklerinin yedi boyut altında toplandığını göstermiștir. Yapılan fark analizleri sonucunda; yönetici yetkinliklerinin; yöneticinin eğitim durumuna, yönetim kademesine, çalıșma süresine, çalıștığı bölümlere, otel sınıfına göre fark gösterdiği, otel türüne göre ise fark göstermediği belirlenmiștir. Elde edilen sonuçların, geleceğin otel yöneticilerine, insan kaynakları yöneticilerine ve turizm eğitimi veren kurumlara faydalı olacağı düşünülmektedir.
\end{abstract}

\section{Giriş}

Otel işletmeleri, tüketici tercihlerine müdahalede bulunamama kısıtını, işletmede etkili bir yönetim uygulayarak ve mevcut müşterilerinin memnun ayrılmasını sağlayarak avantaja dönüştürebilir (Kozak vd. 2013:105). Müşteri memnuniyeti ise kaliteyle sağlanırken, kaliteli hizmeti destekleyen yönetsel yetkinliklerdir (Shemwell, Yavas ve Bilgin 1998; Agut, Grau ve Perio 2003). Ayn zamanda yatırımların başarısında da ana faktör yönetim- sel kalite ve yetkinlikler olarak kabul görmektedir (Jeou-Shyan vd. 2011). Bir örgütü yönetmek, işle ilgili görevler ile değişen çevreyi uyumlaştırmayı içermektedir (Agut, Grau ve Perio 2003). Bunun yanında bilgi ve beceriye dayalı geleneksel yönetim yetersiz kaldığından, son dönemlerde geniş yönetsel yetkinlikler tanımlanmıştır. Yetkinlikler, işe yönelik kişide istenen ya da gerekli olan bilgi, beceri, yetenek, tutum ve özellikleri içermektedir (Perdue, Woods ve Ninemeier 2001; Suh, West ve Shin 2012). 
Günümüzde artan rekabet ve değişimin etkin olduğu küresel ekonomik ortamda, turizm öğrencileri, eğitimcileri ve yöneticileri için geleceğin endüstri liderlerinin yetkinliklerini anlamak, önemli hale gelmiştir. Yetkinlik çalışmaları, işletmelerin insan kaynakları programlarını, performans yönetim sistemlerini, eğitim ve gelişim araçlarını, işgören tutundurma uygulamalarını ve örgütsel gelişim stratejilerini geliştirmesi (Gangani, McLean ve Braden 2006) yönü ile de önem kazanmaktadır. Dünya Turizm Örgütü'nün (Tourism Highlights 2014 Edition) 2013 yılı verilerine göre Türkiye, ağırladığ1 turist sayısı bakımından dünyada altıncı, turizm gelirleri açısından da 12'inci sırada (UNWTO 2014) yer almaktadır. Dünya Ekonomik Forumu'nun hazırladı $\breve{g}_{1} 2013$ Seyahat ve Turizmde Rekabetçilik raporunda ise Türkiye'nin Dünya'da 46'incı ve Avrupa'da 28'inci sirada bulunması (Weforum 2013) düşündürücüdür. Rekabette üst sıralara ç1kabilmek için turizm sektörünün tüm bileşenleriyle birlikte otel işletmelerinin de iyi yönetimi önem kazanmaktadır. Kozak ve Yetgin (2013), yetkinliğin personel eğitimi, seçimi ve kariyer planlaması gibi insan kaynakları alanlarında sık sık kullanıldığını, günümüz ihtiyaçlarına göre mesleki görev tanımlarının yanında yetkinliklerin de ortaya konulması gerektiğini vurgulamaktadırlar. Yöneticilerin başarısında yetkinliklerin oynadığı etkin rol (Wang ve Tsai 2012), çalışmanın yazarını bu araştırmaya yönlendirmiştir.

Çalışmanın iki amacı bulunmaktadır. Bunlardan ilki, otel yöneticilerinin yetkinliklerini belirlemek, ikincisi de şehir otelleri ile resort otel yöneticilerinin yetkinliklerini karşılaştırmaktır. Çalışmada şehir otelleri ile resort otellerinin farklı özelliklerinin, yöneticilerin yetkinliklerinde de fark yaratıp yaratmadığ 1 sınanmak istenmiştir. Çalışmanın sonucunun konaklama sektöründe kariyer planlayan geleceğin yöneticilerine yararlı olabileceği düşünülmektedir. Bireyler kariyer planlarını yaparken, belirlenen yetkinliklerden yetersiz olduklarını düşündükleri alanlarda gelişim göstermek için çalışma yapabilirler. Turizm eğitimi verilirken de yetkinliklere göre ihtiyaç duyulan konularda eğitime ağırlık verilebilir.

\section{YETKINLIKK KAVRAMI}

Lucia ve Lespinger (1999) yetkinliği, örgütsel rolü etkin bir şekilde gerçekleştirmede ve stratejik hedefleri karşılamada ihtiyaç duyulan, bilgi, beceri, kişisel özellikleri ve davranışları ifade eden araç olarak tanımlamaktadırlar. Brownell (2008) ise yetkinliklerin işte etkili olabilmek için gerekli beceri (öğrenilmiş davranışlar) ya da nitelikler/yetenekler (kişisel özellikler) olduğunu vurgulamıştır. Başka bir tanımda da yetkinliklerin, başarıyla ilişkili beceriler, bilgi, davranışlar, kişisel özellikler ve motivasyonları içerdiği belirtilmektedir (Gangani, McLean ve Braden 2006).

Gangani, McLean ve Braden (2006) yetkinlikleri, genel, işle ilgili ve kişisel olmak üzere üç grupta sınıflandırmışlardır. Birçok çalışmada ise temelde teknik yetkinlikler ve genel yetkinlikler olarak ele alınmıştır (Garavan ve McGuire, 2001; Agut, Grau ve Perio 2003; Jeou-Shyan vd. 2011). Teknik yetkinlikler işle ilgili profesyonel bilgileri içerirken, genel yetkinlikler bireyle ilişkili, görevleri yerine getirirken yararlandığı ve bireyin karakterini oluşturan motivasyonları, tutumları ve özelliklerini içermektedir (Çizel, Anafatra ve Sarvan 2006).

\section{OTEL YÖNETICILERININ YETKINLIKLERI}

Alanyazın incelendiğinde, ağırlama sektörü yöneticilerinin yetkinliklerini araştıran araştırmacıların, en çok insan kaynakları becerileri üzerinde durdukları görülmektedir. Wang ve Tsai'nin (2012) uluslararası turist otellerindeki restoran yöneticilerinin kariyer yetkinliklerini belirledikleri çalışma$\mathrm{da}$, en önemli yetkinliklerden birincisi işyeri davranışları, ikincisi de iletişim ağı becerisi olarak yer almıştır. İşyeri davranışları olarak; işe karşı tutum, iş etiği, iş güvenliği, sağlık güvencesi ve takım çalışması olarak ele alınmıştır. Brownell'in (2004) Kuzey Amerika'daki lüks ve üst düzey otellerin genel müdürlerinin başarısında ve kariyer gelişiminde önemli olan becerileri ve kişisel özellikleri incelediği araştırmada; becerilerde, takımları yönlendirme, etkili dinleme, çalışanlara koçluk etme, geribildirim verme, anlaşmazlıkları yönetme daha önemli bulunurken, kişisel özellik olarak da çalışkanlık, sözüne güvenirlik ve dürüstlük öne çıkmıştır.

Jeou-Shyan vd.'nin (2011) çalışmalarında Tayvan'daki otel yöneticilerinin yetkinlikleri, 18 boyut altında 107 yetkinlik olarak ele alınmış, en önemli yetkinlik boyutları liderlik, kriz yönetimi ve problem çözme olarak ortaya çıkmıştır. Diğer bir çalışmada Agut, Grau ve Perio (2003), İspanya'da otel 
ve restoran yöneticilerinin yetkinlik gereksinimlerini; teknik yetkinlikler (bilgisayar, yabancı dil ve ekonomik-finansal) ve genel yetkinlikler (etkinlik, öz denetim ve sosyal ilişkiler) olarak belirlemişlerdir. Çizel, Anafatra ve Sarvan'ın (2006) yaptığı benzer bir çalışmada, Antalya'da otellerin orta kademe yöneticilerinin ihtiyaç duydukları yetkinliklerde, pazarlama ve pazar araştırmaları ile ekonomik ve finansal yönetim birinci sırada yer almıştır. Kay ve Moncars (2004) da benzer şekilde, otel yöneticilerinin kariyer başarısında finansal yönetimin önemine vurgu yapmıştır.

Suh, West ve Shin (2012) çalışmalarında otel yöneticileri ve öğrencilerden topladıkları verileri analiz ederek geleceğin ağırlama endüstrisi yöneticilerinin başarısında önemli olan yetkinlikleri; konukseverlik becerileri, kişisel ilişkiler becerileri, denetim becerileri, yiyecek-içecek yönetimi becerileri, liderlik ve iletişim becerileri olarak belirlemişlerdir.

Pirnar'ın (2014) İzmir'de otel yöneticilerinin görüşlerini aldığı çalışmasında, etkin otel yöneticileri için; "verimlilik yönetimi, maliyet, tutundurma, yaratıcılık, müşteri ilişkileri, sosyal medya, etkin bütçeleme, eğilimleri yönetme, pazarlama, yenilikçi hizmetler, sürdürülebilir hizmetler, müzakere, zaman yönetimi, kriz yönetimi, kalite yönetimi, sosyal sorumluluk ve etik standartlar" geliştirilmesi gereken önemli alanlar olarak belirlenmiştir. Çalışmada, otel yöneticilerinin, kültürel farklılığı anlama, ekip oluşturma, liderlik özellikleri, koordinasyon, etik ve sürdürülebilirliği anlama ve iletişim bilgisi ile karar verme bilgilerine sahip olmalarının beklendiği ortaya çıkmıştır.

Kültür farkının yönetici yetkinliklerinde etkili olacağ1 görüşü birçok araştırmacı (Hoskisson vd. 2000; Jeou-Shyan vd. 2011) tarafından savunulmaktadır. Mesleki yetkinliklerin birey merkezli olmasından dolayı, farklı kültürlere sahip ülkelerde mesleki yetkinliklerin değerlendirilmesinde özelliklere verilen önemin farklı olduğu (Le Deist ve Winterton 2005; Jeou-Shyan vd. 2011) görülmüştür. Zaman içerisinde gerek duyulan yetkinliklerin değiştiği de (Chung 2000) kabul edilmektedir. Farklı ülkelerde otel yöneticilerinin yetkinliklerini araştıran birçok çalışma olmasına rağmen Türkiye'de faaliyet gösteren otellerdeki yöneticilerin yetkinliklerinin araştırıldığı çalışma sayısı oldukça azdır.

\section{ŞEHIR OTELLERI VE RESORT OTELLER}

Alanyazındaki araştırmaların daha çok otel yöneticilerinin yetkinliklerinin diğer sektörlerdeki yönetici yetkinliklerinden farklılığına odaklandığı, farklı çevre koşullarının otel yöneticilerinin yetkinlikleri üzerine etkilerinin araştırıldığı çalışmaların ise oldukça az olduğu görülmüştür (Brownell 2008). Brownell'in (2008) otel yöneticilerinin yetkinlikleri ile kurvaziyer yöneticilerinin yetkinliklerini karş1laştırdığı çalışmada, olumlu tutum ve etkili dinleme gibi temel yetkinliklerde farkl1lık bulunmazken, her bir endüstriye özel olan yetenek ve becerilerin önemlerinde farklılık bulunmuştur. Agut, Grau ve Perio (2003), Brownell (2008), Jeou-Shyan vd. (2011) ve Horng ve Lin (2013) otel yöneticilerinin yetkinliklerinde bireysel koşulların ve çevre koşullarının etkisini görmek için yeni çalışmalara ihtiyaç olduğunu belirtmektedirler.

Alanyazın taramasında şehir otelleri yöneticileri ile resort otelleri yöneticilerinin yetkinliklerinin karşılaştırıldığ 1 bir çalışma yapılmadığ 1 da görülmüştür. Şehir otelleri ile resort oteller birçok yönden farklılık göstermektedir. Şehir otellerinin müşterileri genellikle iş amaçlı seyahat edenlerden oluşmakta iken resort otel müşterileri tatil amaçlı seyahat etmektedirler (Oral 2005; Kozak vd. 2013). Müşteri türüne göre otellerin hizmet türleri de değişiklik göstermektedir. Şehir otelleri 12 ay hizmet veren işletmeler iken resort oteller tatil türüne göre mevsimsellik göstermektedir (Oral 2005; Kozak vd. 2013). Otellerin işgörenleri de otelin konumuna, verilen hizmet türüne ve çalışma sürelerine göre farklılık göstermektedir. Bu koşulların yönetici yetkinliklerinde fark yaratıp yaratmadığ 1 bu çalışmanın araştırma sorusudur.

Alanyazın taramasında, Türkiye'de faaliyet gösteren otellerin yöneticilerinin yetkinliklerinin incelenmesi konusunda boşluk olduğu görülmüştür. Farklı bireysel özelliklerde ve farklı çevre koşullarında faaliyet gösteren otellerin yöneticilerinin yetkinliklerinin araştırılması, çalışmanın özgün yönünü oluşturmaktadır. Daha önceki çalışmalarda otel yöneticilerinin yetkinliklerinin neler olması gerektiği ve yetkinliklerin önemi araştırılırken, bu çalışmada yöneticilerin sahip oldukları yetkinlikler ve bu yetkinliklerin koşullara göre değişiklik gösterip göstermediği araştırılmıştır.

$H_{1}$ : Yöneticilerin yetkinlikleri arasında çalışılan otel türüne göre fark vardır. 
Bu hipotez $\left(\mathrm{H}_{1}\right)$ şehir oteli yöneticileri ile resort otel yöneticilerinin yetenekleri arasında fark olup olmadığını görmek için oluşturulmuştur.

$\mathrm{H}_{2}$ : Yöneticilerin yetkinlikleri arasında çalışılan otel stnifına göre fark vardır.

Çalışmaya üç, dört ve beş yıldızlı oteller dâhil edilmiş, otel sınıfına göre yönetici yetkinliklerinin farklı olup olmadığını belirlemek için bu hipotez $\left(\mathrm{H}_{2}\right)$ oluşturulmuştur.

$\mathrm{H}_{3}$ : Yöneticilerin yetkinlikleri arasinda bulundukları yönetim kademesine göre fark vardır.

Otel yöneticileri üst, orta ve alt kademe yöneticiler olarak ayrılmış, yöneticilerin bulundukları kademeye göre yetkinliklerinde fark olup olmadığını belirlemek için $\mathrm{H}_{3}$ hipotezi oluşturulmuştur.

$H_{4}$ : Yöneticilerin yetkinlikleri arasında çalışılan otel bölümlerine göre fark vardır.

Otellerde bulunan bölümlerde birbirinden oldukça farklı işler yapılıyor olmasının yöneticilerinin yetkinliklerinde fark olup olmadığını belirlemek için $\mathrm{H}_{4}$ hipotezi oluşturulmuştur.

$H_{5}$ : Yöneticilerin yetkinlikleri arasında aldıkları eğitim düzeyine göre fark vardır.

$H_{6}$ :Yöneticilerin yetkinlikleri arasında turizm eğitimi alıp almamalarnna göre fark vardır.

Otel yöneticilerinin aldıkları eğitim düzeyine ve turizm eğitimi alıp almamış olmalarına göre sahip oldukları yetkinliklerde fark olup olmadığını belirlemek için $\mathrm{H}_{5}$ ve $\mathrm{H}_{6}$ hipotezleri oluşturulmuştur.

$H_{7}$ : Yöneticilerin yetkinlikleri arasında çalı̧ma sürelerine göre fark vardir.

$H_{8}$ : Yöneticilerin yetkinlikleri arasında yaşlarına göre fark vardir.

Çalışmanın son hipotezleri de (H7 ve H8) yöneticilerin çalıştıkları süreye ve yaşlarına göre sahip oldukları yetkinliklerde fark olup olmadığını belirlemek için oluşturulmuştur.

\section{YÖNTEM}

Çalışmada nicel yaklaşım benimsenmiş, alan araştırması yöntemi kullanılmıştır. Alan araştırmasında anket tekniği uygulanmıştır. Anketin yapılandı- rılması aşamasında ön araştırma yapılarak, yazın taramasından elde edilen bilgiler değerlendirilmiş ve ampirik çalışmalarda kullanılan ölçekler incelenmiştir. Daha sonra 58 ifadeden oluşan JeouShyan vd.'nin (2011) ve 22 ifadeden oluşan Agut, Grau ve Perio'nun (2003) geliştirdikleri ölçeklerden yararlanılarak soru listesi oluşturulmuştur. Oluşturulan ifadeler, anlaş1lır ve sektöre uyumlu olması için üç akademisyen ve iki profesyonel yönetici olmak üzere beş uzman tarafından gözden geçirilmiş, 61 ifadeden oluşan ölçek hazırlanmıştır. Böylelikle içerik geçerliliği sağlanmıştır.

Anket formu, iki bölümden oluşmaktadır. İlk bölümde otel yöneticilerinin yetkinliklerine ilişkin ifadeler yer alırken, ikinci bölümde katılımcıların demografik özellikleri ile çalıştıkları otele yönelik ifadelere yer verilmiştir. Yetkinlikler listesi kişiler arası ilişkiler, iletişim, liderlik, uygulama, stratejik yönetim, analiz, sorun çözme, insan kaynakları yönetimi, operasyon yönetimi, uzmanlık bilgisi, finansal yönetim, pazarlama, kültür, öz yönetim, tutum ve yabancı dil alanlarından oluşmaktadır. Ankette otel yöneticilerinin yetkinliklere sahip olma dereceleri beşli tutum ölçeği ile (hiç-tamamen) ölçülmüştür.

Alan araştırması İzmir'de gerçekleştirilmiştir. İzmir, şehir otelleri ve sayfiye otellerin bulunduğu bir destinasyon olduğu için çalışma alanı olarak seçilmiştir. Çeşme, İzmir' in en çok sayfiye oteli olan ilçesidir. İzmir'in merkez ilçesi Konak'ta 61 şehir oteli, Çeşme'de 50 sayfiye oteli bulunmaktadır (İzmir Kültür ve Turizm Müdürlügü 2013). Çalışmaya tüm üç, dört ve beş yıldızlı oteller dahil edilmek istenmiş, ancak çalışmaya katılmayı kabul eden otel sayısı Konak'ta 12, Çeşme'de 11 olarak gerçekleşmiştir.

Veriler 2013 yılının Eylül ve Ekim aylarında alt, orta ve üst kademe otel yöneticilerden toplanmıştır. Anketler otel yöneticilerinin tercihiyle bazı otellerde yüz yüze doldurulmuş, bazı otellerde ise anket formları bırakılmış bir hafta sonra geri alınmıştır. Daha sonra teslim alınan anketlerin geri dönüş oranı \%52'dir. Bazı yazarların da (Lukas 1999; JeouShyan vd. 2011) vurguladığı gibi otellerde çalışma yürütmek güç olabilmektedir. Analize uygun elde edilen veri sayısı ise 162 'dir. İzmir merkez ve Çeşme'deki otellerdeki yönetici sayılarına ulaşılamadı$\breve{g} 1$ için gerçek evren tespit edilememiştir. Toplamda 23 otel çalışmaya katılmayı kabul ettiğinden, her 
otelde ortalama on yönetici olduğu varsayılarak, evren 230 kabul edildiğinde, 162 örneklem birimi, evreni temsil etmede yeterli olmaktadır (Sekaran ve Bougie 2010). Verilerin analizinde parametrik veya parametrik olmayan testlerin hangilerinin kullanılması gerektiğine karar verebilmek için çarpıklık (Skewness) ve basıklık (Kurtosis) değerlerine bakılmıştır. Verilerin normal dağıldı̆̆ edildiği için veri analizinde parametrik testler kullanılmıştır. Verilerin analizinde SPSS 20 programı kullanılarak, frekans dağılımı, güvenilirlik analizi, faktör analizi yapılmış, hipotezler t-testi ve varyans analizi ile sınanmıştır.

\section{BULGULAR}

Çalışmaya katılan bireylere ve bu bireylerin çalıştıkları otele ait özellikler Tablo 1'de verilmiştir. Tablo 1 incelendiğinde, çalışmaya katılan otel yö-

Tablo 1. Katılımcılara ve Çalıştıkları Otellere İlişkin Özellikler Tablosu

\begin{tabular}{|c|c|c|c|c|c|}
\hline & Sayı (N) & Yüzde (\%) & & Sayı $(N)$ & Yüzde (\%) \\
\hline \multicolumn{3}{|l|}{ Yaş } & \multicolumn{3}{|l|}{ Otelin Sınıfı } \\
\hline $21-30$ & 45 & 27,8 & 5 yıldız & 96 & 59,3 \\
\hline $31-40$ & 66 & 40,7 & 4 yıldız & 27 & 16,7 \\
\hline $41-50$ & 43 & 26,5 & 3 yıldız & 37 & 22,8 \\
\hline 51 ve üstü & 8 & 4,9 & Bölümler & & \\
\hline \multicolumn{3}{|l|}{ Cinsiyet } & Genel Müdür ve Yardımcısı & 16 & 9,9 \\
\hline Kadın & 47 & 29,0 & Odalar Bölümü & 40 & 24,7 \\
\hline Erkek & 115 & 71,0 & Yiyecek-içecek Bölümü & 41 & 25,3 \\
\hline \multicolumn{3}{|l|}{ Medeni Durum } & Ofisler & 42 & 25,9 \\
\hline Evli & 89 & 54,9 & Diğer Bölümler & 18 & 11,1 \\
\hline Bekâr & 72 & 44,4 & Çalışma Süresi & & \\
\hline \multicolumn{3}{|l|}{ Eğitim } & $1-3$ yıl & 15 & 9,3 \\
\hline Lise & 44 & 27,2 & 4-6 yıl & 27 & 16,7 \\
\hline Üniversite & 117 & 72,2 & 7- 9 yıl & 37 & 22,8 \\
\hline \multicolumn{3}{|l|}{ Turizm Eğitimi } & 10 yıldan fazla & 82 & 50,6 \\
\hline Var & 60 & 37 & Yönetim Kademesi & & \\
\hline Yok & 102 & 63 & Üst kademe & 20 & 12,3 \\
\hline \multicolumn{3}{|l|}{ Otelin Konumu } & Orta Kademe & 70 & 43,2 \\
\hline İzmir (Şehir Oteli) & 59 & 36,4 & Alt Kademe & 72 & 44,4 \\
\hline \multicolumn{2}{|c|}{ Çeşme (Sayfiye Oteli) 103} & 63,6 & & & \\
\hline
\end{tabular}

neticilerinin \%71'inin erkek, \%66,7'sinin üniversite mezunu, \%50,6' sının on yıldan fazla süre çalıştığ görülmektedir. Katılımcıların \%44,4'ü turizm eğitimi almış ve \%40,7'si 31-40 yaş aralığındadır.

\section{Güvenilirlik ve Geçerlik}

Araştırmada kullanılan, Otel Yöneticilerinin Yetkinlikleri ölçeğinin güvenirlik katsayısı (Cronbach's Alpha) 0,962 olarak bulunmuştur. Bu değer, sosyal bilimler araştırmaları için kabul edilen alfa değeri olan 0,80 düzeyinin üzerinde gerçekleştiğinden, araştırmada kullanılan ölçeğin oldukça güvenilir olduğu söylenebilir (Nunnally 1967).

Çalışmada ölçeğin yapı geçerliliği açıklayıcı faktör analizi (AFA) ile gerçekleştirilmiştir. Daha anlamlı ve yorumlanabilir bir çözüm elde etmek için, 
düşük yüklü ya da aynı anda birden fazla faktöre yük veren ifadelerin silinmesi gerekmiştir (Hair vd. 2006). Veri setinin faktör analizi için uygunluğunun değerlendirilmesinde Barlett's Testi (Barlett's
Test of Sphericity) ve Kaiser-Meyer-Olkin (KMO) Örneklem Yeterliliği Ölçütü kullanılmaktadır.

Otel yönetici yetkinlikleri ölçeğinde yapılan faktör analizi sonucunda Bartlett's Testi sonucu

Tablo 2. Otel Yöneticilerinin Yetkinliklerine İlişkin Faktör Analizi Tablosu

\begin{tabular}{|c|c|c|c|c|c|}
\hline & Faktör Yükü & Özdeğer & Ortalama & $\begin{array}{c}\text { Açıklanan } \\
\text { varyans \% }\end{array}$ & $\alpha$ \\
\hline Faktör 1: Kriz Yönetimi & & 12,258 & 4,206 & 19,408 & ,930 \\
\hline Çözümün etkisini değerlendiririm. & ,780 & & & & \\
\hline Çözümü uygularım. &, 761 & & & & \\
\hline Olası krizleri belirler ve önlerim. & ,758 & & & & \\
\hline Krizi etkili olarak ele alırım. &, 757 & & & & \\
\hline Sorunu tespit eder incelerim. & ,752 & & & & \\
\hline Sorunlara çözüm bulurum. & ,715 & & & & \\
\hline Çalışanlara gelişim fırsatları sunarım. &, 601 & & & & \\
\hline Çalışanları karar vermede desteklerim. &, 585 & & & & \\
\hline Güvenlik tehlikesini yönetirim. &, 557 & & & & \\
\hline Çalışanlar arasında işbirliği sağlarım. &, 500 & & & & \\
\hline Faktör 2: Yenilikçilik & & 2,651 & 4,039 & 13,051 &, 869 \\
\hline Yaratıcı ürünler için plan yaparım. & ,770 & & & & \\
\hline Otelde yaratıcı gelişime ortam sağlarım. &, 717 & & & & \\
\hline Kararların uygulanabilirliğini değerlendiririm. & ,644 & & & & \\
\hline Otele yenilik ve farklılaşma getiririm. &, 638 & & & & \\
\hline Üretim ve verimliliği geliştiririm. &, 607 & & & & \\
\hline Yenilikçi stratejiler hazırlar ve uygularım. &, 557 & & & & \\
\hline Faktör 3: Yabancı Dil & & 2,589 & 3,807 & 9,266 &, 954 \\
\hline Yabancı dilde yazma yeteneğine sahibim. & ,909 & & & & \\
\hline Yabancı dilde okuma yeteneğine sahibim. & ,901 & & & & \\
\hline Yabancı dilde iletişim yeteneğine sahibim. & ,894 & & & & \\
\hline Faktör 4:Öz Denetim & & 1,418 & 4,239 & 8,205 & , 744 \\
\hline İş-yaşam dengemi kurarım. &, 779 & & & & \\
\hline Kişisel sağlığıma dikkat ederim. & ,754 & & & & \\
\hline Duygularımı yönetirim. &, 752 & & & & \\
\hline İş etiğine uygun davranırım. &, 575 & & & & \\
\hline Faktör 5: Analiz & & 1,334 & 4,004 & 7,828 & ,863 \\
\hline Gelecekteki pazar eğiliminin analizini yaparım. & ,833 & & & & \\
\hline Sektörel durum analizi yaparım. & ,775 & & & & \\
\hline Rekabet analizi yaparım. &, 756 & & & & \\
\hline Faktör 6: Kişiler Arası İletişim & & 1,249 & 4,348 & 6,499 & ,800 \\
\hline Halkla ilişkiler becerilerine sahibimdir. &, 834 & & & & \\
\hline Uzlaşma becerisine sahibimdir. &, 797 & & & & \\
\hline İkna kabiliyetim vardır. & ,498 & & & & \\
\hline Faktör 7:Kişisel Gelişim & & 1,079 & 4,259 & 6,298 &, 619 \\
\hline Kişisel gelişimimi sürdürürüm. & ,800 & & & & \\
\hline Kendime meydan okurum. & ,711 & & & & \\
\hline Zamanı verimli yönetirim. &, 566 & & & & \\
\hline
\end{tabular}

Kaiser-Meyer-Olkin Örneklem Ölçümü =,880; Bartlett's Test of Sphericity =3345,053; Toplam farkın (Varyans) açıklama oranı: 70,556 
3345,053 ve p anlamlılık değeri 0,000 olarak gerçekleşmiştir ki bu değer değişkenler arasında yüksek bir korelasyon olduğunu ifade etmektedir. KaiserMeyer-Olkin (KMO) örneklem değeri 0,880'dir. Değerler faktör analizi uygulamak için yeterli düzeyde gerçekleşmiştir (Eroğlu 2008). Faktör yapısını belirlemek ve anlamlı yorumlanabilir faktörler elde etmek amacı ile temel bileşenler analizi ve varimaks rotasyonu teknikleri kullanılmış, özdeğer istatistiği birden büyük olan ve faktör yükü 0,30'un üzerinde olan veriler dikkate alınmıştır. Verilere ilişkin faktör analizi sonuçları Tablo 2'de sunulmuştur.

Tablo 2 incelendiğinde otel yöneticilerinin yetkinliklerinin yedi boyutta toplandığı görülmektedir. İlk boyut "Kriz Yönetimi" olarak adlandırılmıştır. Yöneticilere yetkinliklere sahip olma dereceleri sorulmuştur. Kriz yönetimi boyutundaki ifadeler; krizin fark edilmesi, önlenmesi, yönetilmesi, çözülmesine ilişkindir. "Yenilikçilik" olarak adlandırılan ikinci boyut, yaratıcılığın geliştirilmesi ve uygulanmasına yönelik ifadelerden oluşmaktadır. Üçüncü boyut "Yabancı dil"; yabancı dilde okuma, konuşma ve iletişim becerilerini içermektedir. "Öz-Denetim" olarak adlandırılan dördüncü boyut da; iş-yaşam dengesi, kişisel sağlıkla ilgili ifadelerden oluşmaktadır. Beşinci boyut "Analiz" boyutu; pazar eğilimleri, sektörel durum ve rekabet analizini içermektedir. "İletişim” boyutunda halkla ilişkiler, uzlaşma ve ikna becerileri yer almaktadır. En son boyut "Kişisel Gelişim" olarak adlandırılmıştır. Tablo 2 incelendiğinde katılımcıların boyutlar içinde iletişim boyutuna en yüksek puanı vermeleri nedeniyle, yöneticilerin en fazla sahip oldukları yetkinliğin kişiler arası iletişim olduğu görülmektedir.

\section{Hipotez Testleri}

Çalışmanın hipotezlerini sınamak için verilere t-testi ve varyans analizi uygulanmıştır. Tablo 3'te t-testi ve varyans analizi testi sonuçları yer almaktadır. Yönetici yetkinliklerinin otel türlerine göre fark gösterip göstermediğini belirlemek için yap1lan t-testi sonucunda anlam düzeyi 0,05'ten büyük çıktığı için istatistiksel olarak fark olmadığı görülmüştür. Bu nedenle $\mathrm{H}_{1}$ hipotezi reddedilmiştir. Yönetici yetkinliklerinin yaşa göre fark gösterip göstermediğini belirlemek için yapılan varyans analizi sonucunda anlam düzeyi 0,05'ten büyük olduğu için istatistiksel olarak fark olmadığ görülmüştür. $\mathrm{Bu}$ nedenle $\mathrm{H}_{8}$ hipotezi de reddedilmiştir.
Otel yöneticilerinin yetkinliklerinde, otel sınıfına göre yapılan varyans analizi sonucunda; kriz yönetimi, yenilikçilik ve yabancı dil boyutlarında anlamlı farklılık bulunmuştur. Bu sonuçla $\mathrm{H}_{2}$ hipotezi kabul edilmiştir. Otel yöneticilerinin bulundukları yönetim kademesine göre "analiz yetkinliği" boyutunda anlamlı bir fark gözlenmiştir. Analiz yetkinliğinin en çok üst kademede, sırasıyla orta ve alt kademede bulunduğu görülmüştür. $\mathrm{H}_{3}$ hipotezi kabul edilmiştir. Bölümlere göre yönetici yetkinlikleri yalnızca analiz yetkinliğinde fark göstermiştir. Analiz yetkinliği en çok üst yönetimde, sonra odalar bölümünde, ofislerde, yiyecek-içecek bölümünde, son olarak da diğger bölümlerde bulunmaktadır. $\mathrm{H}_{4}$ hipotezi kabul edilmiştir.

Eğitim durumuna göre yönetici yetkinlikleri, yabancı dil ve analiz boyutlarında farklılık göstermiştir. $\mathrm{H}_{5}$ hipotezi kabul edilmiştir. Katılımcıların turizm eğitimi alıp almamalarına göre yönetici yetkinliklerinden yenilikçilik boyutunda fark bulunmuştur, $\mathrm{H}_{6}$ hipotezi kabul edilmiştir. Yetkinlikler yöneticilerin çalışma sürelerine göre, yenilikçilik boyutunda fark göstermiştir. Yenilikçilik yetkinliğinin en çok 10 yıldan fazla çalışma süresine sahip yöneticilerde bulunduğu belirlenmiştir. $\mathrm{H}_{7}$ hipotezi kabul edilmiştir.

\section{TARTIŞMA VE SONUÇ}

Otel yöneticilerinin yetkinliklerinin araştırıldığ 1 bu çalışmada, yetkinliklerin yedi boyut altında toplandığı görülmüştür. Boyutlar sırasıyla; kriz yönetimi, yenilikçilik, yabancı dil, öz denetim, analiz, kişiler arası iletişim ve kişisel gelişimden oluşmaktadır. Yetkinlikler, Jeou-Shyan vd.'nin (2011), Suh, West ve Shin'in (2012), Testa ve Sipe'nin (2012) ve Horng ve Lin'in (2013) çalışmalarında bulunan otel yönetici yetkinlikleriyle benzerlik göstermektedir. Kriz yönetimi yetkinliğinin ilk boyut olarak ortaya çıkması, dünyada yaşanan ve kaçınılmaz olarak turizm sektöründe de hissedilen ekonomik krizin sonucu olarak doğal karşılanabilir. Benzer şekilde Jeou-Shyan vd.'nin (2011) çalışmalarında da kriz yönetimi önemli bir yetkinlik olarak belirlenmiştir. Kriz yönetimi boyutunda faktör yükü en yüksek olan ifade de "krizde çözümlerin sonuçlarının değerlendirilmesi” olduğu görülmüştür. 2008 küresel finansal kriz sonrasında uygulanan çözüm yollarının değerlendirmesinin yapıldığı dönem olması nedeniyle bu sonucun elde edildiği düşünülebilir. 
Tablo 3. Otel Yöneticilerinin Yetkinliklerine Yönelik Fark Analizleri Tablosu

\begin{tabular}{|c|c|c|c|c|c|c|c|}
\hline & Kriz Yönetimi & Yenilikçilik & Yabancı dil & Öz Denetim & Analiz & İletişim & Kişisel Gelişim \\
\hline \multicolumn{8}{|l|}{ Otelin Sınıfı } \\
\hline 5 Yıldız & 4,3634 & 4,2194 & 3,8646 & & & & \\
\hline 4 Yıldız & 4,1477 & 4,0741 & 4,1852 & & & & \\
\hline 3 Yıldız & 3,8502 & 3,7523 & 3,4324 & & & & \\
\hline F-test & 10,634 & 6,345 & 4,422 & & & & \\
\hline Anlam Düzeyi &, 000 & ,002 &, 014 & & & & \\
\hline \multicolumn{8}{|l|}{ Yönetim Kademesi } \\
\hline Üst Kademe & & & & & 4,4167 & & \\
\hline Orta Kademe & & & & & 4,1214 & & \\
\hline Alt Kademe & & & & & 3,8241 & & \\
\hline F-test & & & & & 4,874 & & \\
\hline Anlam düzeyi & & & & &, 009 & & \\
\hline \multicolumn{8}{|l|}{ Bölümler } \\
\hline Üst Yönetim & & & & & 4,3125 & & \\
\hline Odalar & & & & & 4,2833 & & \\
\hline Yiyecek-İçecek & & & & & 4,2439 & & \\
\hline Ofisler & & & & & 4,2619 & & \\
\hline Diğer & & & & & 4,2407 & & \\
\hline F-test & & & & & 3,202 & & \\
\hline Anlam Düzeyi & & & & &, 015 & & \\
\hline \multicolumn{8}{|l|}{ Eğitim } \\
\hline Lise & & & 2,9470 & & 3,6970 & & \\
\hline Üniversite & & & 4,1254 & & 4,1410 & & \\
\hline Anlam Düzeyi & & &, 000 & & ,003 & & \\
\hline \multicolumn{8}{|l|}{ Turizm Eğitimi } \\
\hline Var & & 4,2765 & & & & & \\
\hline Yok & & 3,9863 & & & & & \\
\hline Anlam Düzeyi & & ,025 & & & & & \\
\hline \multicolumn{8}{|l|}{ Çalışma süresi } \\
\hline $1-3$ yıl & & 3,9889 & & & & & \\
\hline 4-6 yıl & & 3,8086 & & & & & \\
\hline $7-9$ yıl & & 3,9414 & & & & & \\
\hline 10 yıldan fazla & & 4,2691 & & & & & \\
\hline F-test & & 4,135 & & & & & \\
\hline Anlam Düzeyi & &, 007 & & & & & \\
\hline
\end{tabular}

İkinci boyut yenilikçilik (yaratıcılık), yoğun rekabet ortamında işletmelerin hayatta kalması için en önemli araçlardan biri olması nedeniyle öne çıkmaktadır. Yenilikçilik için ortam oluşturulmas1, buna destek verilmesi yöneticilerin yetkinlikleri arasında önemli bir yere sahiptir. Bu sonuç, Pirnar'ın (2014) çalışmasındaki bulguları desteklemektedir. Yabancı dil boyutu, küreselleşme ve müşterilerinin büyük çoğunluğunun yabancı tu- ristler ve tur operatörleri olmasından dolayı otel yöneticileri için önemli bir yetkinliktir. Benzer bir sonuç Agut, Grau ve Perio'nun (2003) İspanya'da otellerde yaptığ 1 çalışmada da ortaya çıkmıştır. Farklı dili konuşan turistleri ağırlamaları nedeniyle yabancı dil bilgisi Türkiye ve İspanya'da gereklilik göstermektedir. Bu durum İzmir için de geçerlidir. İş-yaşam dengesi, duygularını yönetmek ve etiği içeren öz denetim, yönetim yetkinlikleri içinde 
yer almaktadır. Bu sonuç, Agut, Grau ve Perio'nun (2003) ve Jeou-Shyan vd.'nin (2011) çalışmalarını desteklemektedir. Analiz yetkinliği, yöneticilerin planlamada, karar vermede, denetimde kullandığ1 bir yetkinliktir. Otel işletmeleri insan ilişkilerinin yoğun olduğu işletmeler olması dolayısıyla bu işletmelerde kişiler arası iletişim de öne çıkmaktadır. Çalışmada, yetkinlik boyutlarından en yüksek ortalama iletişim boyutunda ortaya çıkmıştır. İletişim becerisi, alanyazın tarama kısmında yer verilen birçok çalışmada otel yöneticilerinde ortak bir yetkinlik olarak belirlenmiş̧ir. Yöneticilerin olduğu gibi operasyonel personelin yetenekleri arasında da iletişim, sosyal ve bireyler arası rollerin ön planda olduğu çalışmalarla (Kozak ve Özdemir 2013) desteklenmektedir.

Çalışmada, uygulanan fark analizlerinde yönetici yetkinliklerinin, yöneticilerin çalıştığı otelin sınıfına, bulundukları yönetim kademesine, bölümüne, eğitim durumuna, turizm eğitimi alıp almamasına ve çalışma süresine göre fark gösterdiği belirlenmiştir. Ancak yöneticilerin yetkinliklerinin, çalıştıkları otelin türüne göre fark göstermediği görülmüştür. Farklı çevre koşullarının, yöneticilerin yetkinliklerinde fark yaratacağ 1 beklentisi bu çalışmanın sonuçları ile desteklenmemiştir. Konak ve Çeşme'nin birbirlerine yakın destinasyonlar olmaları ya da Çeşme'de bulunan resort otellerin genelde zincir oteller olması, bu sonuçta etkili olmuş olabilir.

Kriz yönetimi ve yenilikçilik yetkinliklerinin en çok beş yıldızlı otel yöneticilerinde, ardından sırasıyla dört yıldızlı ve üç yıldızlı otel yöneticilerinde mevcut olduğu görülmüştür. Otelin yıldız sayısı arttıkça bu yeteneklere sahipliğin de arttığı analizlerle bulunmuştur. Çalışmaya katılan yöneticilerin analiz yetkinliğinin yönetim kademesine göre arttığ belirlenmiş̧ir. Bu durum, üst yönetimin zamanının daha büyük kısmını analize ayırmasının doğal sonucu olarak görülebilir. Bu sonuç Chung'ın (2000) çalışmasını da desteklemiştir. Çetinkaya da (2009) farklı sektörlerde gerçekleştirdiği çalışmasında yönetim kademesine göre yetkinliklerin farklllık gösterdiğini belirlemiştir. Çalışılan bölümlere göre, üst yönetimin ve arkasından ön büro bölümündeki yöneticilerin analiz yetkinliği daha yüksektir. Üst yönetimden sonra ön büro bölümünde analizlerin diğer bölümlere göre daha fazla yapıldığı bilinmektedir. Siu'nun (1998) çalışmasında da otellerde farklı departmanlardaki yöneticilerin yetkinlikle- rinin önem derecelerinin değiştiği belirlenmiştir. Üniversite mezunu yöneticilerin, lise mezunlarına göre yabancı dil ve analiz yetkinliklerinin daha fazla olduğu belirlenmiş̧tir. Yöneticilerin aldığı eğitime uygun sonuçlar elde edilmiştir. Turizm eğitimi alan yöneticilerin, almayanlara göre yenilikçilik yetkinliği daha yüksek çıkmıştır. Bu sonucun daha sonraki çalışmalarda, üzerinde durulması gereken bir bulgu olduğu, turizm eğitimlerinde buna ilişkin konuların ağırlıkta olup olmadığı tartışılmalıdır. Çalışmaya katılan yöneticilerin çalışma süresi arttıkça, yenilikçilik yetkinliğinin de arttığı görülmektedir. Uzun süre otelcilik sektöründe çalışan yöneticilerin deneyimleriyle yenilikçiliğin önemini kavramış oldukları düşünülebilir. İletişim, öz denetim ve kişisel gelişim yetkinliklerinde fark ortaya çıkmamasından, sosyal yetkinliklerin çalışmaya katılan yöneticiler açısından aynı derecede gerekli görüldüğü sonucuna varılabilir.

Sınırlı bir örneklem ile yapılmış tek çalışmanın sonuçlarından genelleme yapılması doğru olmamasına rağmen, bulguların daha önce yapılan çalışmaları da desteklediği göz önünde tutularak, otel yönetici adaylarının çalışmada ortaya konulan yetkinliklerini geliştirecek yönde çalışmaları önerilebilir. Yine aynı sonuçlarla, turizm eğitimi veren eğitim kurumlarının belirlenen yetkinliklere yönelik eğitim planlarını gözden geçirmeleri yararlı olabilir.

Çalışmanın birkaç kısıtı bulunmaktadır. Çalışmanın İzmir ile sınırlı olması birinci kısıtıdır. Çalışma ülke genelinde daha yüksek sayıda katılımcı ile tekrar edilerek çevre koşullarının otel yönetici yetkinliklerinde farklılık gösterip göstermediği yeniden sınanmalıdır. Çalışmada nicel yöntem benimsenmiş, kısa sürede çok sayıda örnekleme ulaşılması sağlanmış, ancak; yönetici yetkinliklerinden yenilikçiliğin, turizm eğitimi alıp almamaya ve yöneticinin çalışma sürelerine göre farklıllğı gibi konularda açık uçlu sorularla derinlemesine bilgi alınması gerektiği fark edilmiştir. Bu tespitlerle ileride aynı konunun daha geniş coğrafyada nicel ve nitel yöntemler birlikte kullanılarak araştırılmasi önerilebilir.

\section{KAYNAKÇA}

Agut, S., Grau, R. ve Peiro, J. M. (2003). Competency Needs Among Managers from Spanish Hotels and Restaurants and their Training Demands, Hospitality Management, 22: 281-295. 
Brownell, J. (2004).Ingredients for Success in Career Development, FIU Hospitality Review, 1-17.

Brownell, J. (2008). Leading on Land and Sea: Competencies and Context, International Journal of Hospitality Management. 27: 137-150.

Chung, K. Y. (2000). Hotel Management Curriculum Reform Based on Required Competencies of Hotel Employees and Career Success in the Hotel Industry, Tourism Management, 21: 473-487.

Çetinkaya, M. (2009). Yöneticilerin Yönetsel Yetkinlik Algılamalarına İlişkin Bir Araştırma, Afyon Kocatepe Üniversitesi, I.I.̇.F. Dergisi, 11 (2): 219-239.

Çizel, B., Anafarta, N. ve Sarvan, F. (2007). An Analysis of Managerial Competency Needs in the Tourism Sector: The Case of Turkey, Tourism Review, 62 (2): 14-22.

Eroğlu, A. (2008). Faktör Analizi, Içinde: Kalaycı, Ş. (Editör). SPSS Uygulamalı Çok Değişkenli İstatistik Teknikleri, (ss. 321-331) 3. Baskı, Ankara: Asil Yayın Dağıtım Ltd. Şti.

Gangani, N., McLean, G. N. ve Braden, R. R. (2006). A Competency-Based Human Resource Development Strategy, Performance Improvement Quarterly, 19 (1): 127-139.

Garavan, T. N. ve McGuire, D. (2001). Competencies and Workplace Learning: Some Reflections on the Rhetoric and the Reality, Journal of Workplace Learning, 13 (4): 144-163.

Hair, J. F., Anderson, R. E., Tatham, R. L., ve Black, W. (2006). Multivariate Data Analysis. 6. Bask1. Prentice Hall, New Jersey.

Horng, J. S. ve Lin, L. (2013) Training Needs Assessment in a Hotel Using 360 Degree Feedback to Develop Competency-Based Training Programs, Journal of Hospitality and Tourism Managemnet, 20: 61-67.

Hoskisson, R., Eden, L., Lau, C.M. ve Wright, M. (2000). Strategy in Emerging Economies, Academy of Management Journal, 43: 249-267.

İzmir Kültür ve Turizm Müdürlüğü (2013). http://wwww.izmirturizm.gov.tr/TR,77217/konaklama-verileri.html. Erişim tarihi: 1 Eylül 2013.

Jeou-Shyana, H., Hsuanc, H., Chih-Hsingd, L., Linb, L. ve Chang-Yen, T. (2011). Competency Analysis of Top Managers in the Taiwanese Hotel Industry, International Journal of Hospitality Management, 30: 1044-1054.

Kay, C., Moncarz, E. (2004). Knowledge, Skills, and Abilities for Lodging Management Success, Cornell Hotel and Restaurant Quarterly, 45 (3): 285-298.

Kozak, M. A., Maviş, F., Nergis, H. G. ve Çiçek, D. (2013). Otel İşletmelerinde Yönetim. Ankara: Detay Yayıncilık.

Kozak, M. A. ve Özdemir, C. (2013). Yetenek Kavramının Otel İşletmelerinde Operasyonel Personel Bağlamında Değerlendirilmesi, Seyahat ve Otel İşletmeciliğgi Dergisi/Journal of Travel and Hospitality Management, 10 (1): 6-19.
Kozak, M. A. ve Yetgin, D. (2013). Profesyonel Turist Rehberlerinin (PTR) Yetkinliklerinin Mesleki Yeterlilikler Çerçevesinde Değerlendirilmesi, 14. Ulusal Turizm Kongresi, Erciyes Üniversitesi, Nevşehir, 5-8 Aralık: 408-428.

Le Deist, F. D. ve Winterton, J. (2005). What is Competence?, Human Resource Development International, 8 (1): 27-46.

Lucia, A. D. ve Lesinger, R. (1999). The Art And Science Of Competency Models: Pinpointing Critical Success Factors in an Organization. Jossey-Bass/Pfeiffer, San Francisco.

Lucas, R. (1999). Survey Research. İçinde: Brotherton, B. (Ed.), The Handbook of Contemporary Hospitality Management Research. Wiley, NY: 77-95.

Nunnally, J. C. (1967). Psychometic Theory. New York: McGraw Hill.

Oral, S. (2005). Otel İşletmeciliği ve Verimlilik Analizleri. Beşinci Baskı. Ankara: Detay Yayıncilı.

Perdue, J., Woods, R. H., ve Ninemeier, J. (2001). Club Management Competencies 2005: Updated Information for the Classroom, Journal of Hospitality and Tourism Education, 14 (2): 19-32.

Pirnar, İ. (2014). Specifications for Effective Hotel Managers: View of Izmir Hotels' Managers, Journal of Yasar University, 9 (33): 5583-5596.

Sekaran, U. ve Bougie, R. (2010). Research Methods for Business. John Wiley and Sons, Ltd. UK.

Shemwell, D. J., Yavas, U. ve Bilgin, Z. (1998). Customer-Service Relationships: An Empirical Test of a Model of Service Quality: Test of a Causal Model, Journal of Applied Psychology, 83: 150-163.

Siu, V. (1998). Managing by Competencies-AStudy on the Managerial Competencies of Hotel Middle Managers in Hong Kong, Hospitality Management, 17: 253-273.

Suh, E., West, J. ve Shin, J. (2012). Important Competency Requirements for Managers in the Hospitality Industry, Journal of Hospitality, Leisure, Sport \& Tourism Education, 11: 101-112.

Testa, M. R. ve Sipe, L. (2012). Service-Leadership Competencies for Hospitality and Tourism Management, International Journal of Hospitality Management, 31: 648- 658.

UNWTO (2014). Tourism Highlights 2014 Edition. http:// dtxtq4w60xqpw.cloudfront.net/sites/all/files/pdf/unwto_highlights14_en_hr_0.pdf, Erişim tarihi: 27.Şubat 2015.

Wang, Y.-F. ve Tsai, C-T. (2012). Analysis of Career Competency of Food and Beverage Managers in International Tourist Hotels in Taiwan, International Journal of Hospitality Management, 31: 612-616.

Weforum (2013). http://dtxtq4w60xqpw.cloudfront.net/sites/all/ files/pdflunwto_highlights13_en_hr.pdf, Erişim tarihi: 02 Ocak 2014. 